\title{
ACUTE GLOMERULONEPHRITIS. THE SIGNIFICANCE OF THE VARIATIONS IN THE INCIDENCE OF THE DISEASE ${ }^{1,2}$
}

\author{
BY CHARLES H. RAMMELKAMP, JR., AND ROBERT S. WEAVER 3 \\ (From the Department of Preventive Medicine and the Department of Medicine, Cleveland City \\ Hospital, School of Medicine, Western Reserve University, Cleveland, Ohio; and \\ the Streptococcal Disease Laboratory, Warren Air Force Base, Wyoming)
}

(Submitted for publication December 1, 1952; accepted December 31, 1952)

Acute glomerulonephritis and acute rheumatic fever are considered to be non-suppurative complications of group A streptococcal infections. The mechanism of production of these two sequelae has not been clearly defined nor has the exact relationship of group A streptococcal infections to glomerulonephritis been thoroughly elucidated. It is the purpose of this report to indicate the variability of the occurrence of glomerulonephritis and to present data which may explain the cause of this variation.

\section{EPIDEMIC NEPERITIS}

One of the peculiar epidemiological characteristics of acute glomerulonephritis has been the variability in its occurrence. Although generally considered to be a sporadic disease, occasionally an unusually high incidence of acute nephritis has been recorded both in wide-spread epidemics and in focal outbreaks in small population units.

Considering first the larger epidemics, Wahrer (1) observed 35 patients with acute hemorrhagic nephritis developing in a group of 195 patients with scarlet fever. This high attack rate following scarlet fever was unusual in Wahrer's experience. During World War I, beginning about February, 1915 , a large epidemic of nephritis (termed trench nephritis) occurred among Allied and German troops (2). In a five month period there were more than 1,000 cases reported among British troops alone. Although etiological studies were meager, hemolytic streptococci were isolated from the oropharynx of some patients (3) and the clini-

1 This investigation was supported by the Helen Hay Whitney Foundation, and in part by the Commissions on Acute Respiratory Diseases and Streptococcal Diseases, Armed Forces Epidemiological Board through the Offices of The Surgeons General, Departments of the Army and Air Force, Washington, D. C.

2 Presented in part before the Association of American Physicians, Atlantic City, May, 1952.

3 Fellow of the Youngstown Heart Association, 1952. cal and pathological features were similar to those observed in the nephritis which follows scarlet fever (4).

In 1926 Peace (5) observed 8 patients, each of whom developed nephritis 12 to 14 days after an attack of acute tonsillitis. These patients lived in the same neighborhood within 50 yards of each other. An epidemic of 17 cases of acute nephritis occurred during a three month period in a mental hospital in England (6). During the preceding five years only 1 case of nephritis had been recognized among an average census of 624 patients.

In 1945, 38 patients suffering from acute nephritis were admitted to a clinic in Amsterdam, whereas the average yearly admissions during the preceding 14 years was seven (7). About the same time other epidemics were noted in Holland, England, and Italy. Klein (8) studied 39 cases of nephritis in the period from May through December, $1945 ; 38$ of these patients were seen in a hospital in Groningen. In this group there were six women who were admitted from a political camp during a six week period. In England from 1945 to late 1946, 159 cases of nephritis were admitted to the Greenock Royal Infirmary (9)-a notable increase over former years. Local physicians estimated that there were about five mild cases in the home for each case admitted to the hospital. During the two year period, there were 2 patients from each of two households, and 3 patients from a third household. From five streets there were 5 to 10 patients each. At the time of admission to the hospital, beta-hemolytic streptococci were isolated from the throats of 50 patients. At about the same time Brod (10) reported the occurrence of a relatively large number of cases of nephritis in Italy.

Pratas (11) recorded two small epidemics, one of 10 cases in 1942, and another of 14 cases in 1943. Cascalea, Arias, and Parada (12) observed an epidemic of 23 cases among military person- 
nel in Argentina. Sixteen of the patients came from one infantry regiment and 7 from another regiment. In all of these patients the illnesses began at about the same time.

In addition to these larger epidemics, a number of outbreaks within family units has been described. Addis (13), in his extensive experience, has observed five families in which three or more members were involved and two families where there were two members with nephritis. Klein (8) observed 2 cases in each of three families. Pratas (11) recorded 3 cases of nephritis in siblings. During the course of an epidemic of nephritis, Fleming (9) saw one household with 3 cases, and two housholds with 2 cases of nephritis. In October, 1918, Thomson and MaCauley (14) observed four children with clinical signs of nephritis in a family of eight. Hill (15), in 1919, saw at least three families in which two or more children had nephritis at the same time following illnesses characterized by sore throat. Perhaps the most famous outbreak in a family group is that described by Ernstene and Robb (16). These authors described the occurrence of sore throats in 8 of 10 siblings, and in six of these children signs and symptoms of nephritis developed 7 to 12 days after the onset of the infection.

Schuricht (17), in 1933, described an outbreak of scarlet fever involving seven of a family of 11 children. Of this group, three developed classical signs and symptoms of nephritis, and four others developed hematuria. Ellenberg and Martin (18) observed three siblings who developed acute nephritis at about the same time. Rinkoff, Stern, and Schumer (19) reported 3 cases of nephritis in the same family. Tudor (20) observed an acute respiratory disease in four siblings; two of these developed signs of nephritis, one exhibited hematuria and the fourth was normal. Kilpatrick (21) observed three girls from the same family who were admitted to the hospital with acute nephritis in October, 1944. Gezon (22) studied one family in which the father developed recurrent rheumatic fever and four of six children developed glomerulonephritis within a period of two months. Spink (23) studied a family of seven persons, six of whom had scarlet fever. All six subsequently developed acute glomerulonephritis. Nephritis developed in 5 and possibly 6 of 10 children observed by Martin (24) in Rochester.
Eason, Smith, and Buchanan (25), in a discussion of the possible role of heredity in nephritis, described several outbreaks that were undoubtedly acute glomerulonephritis. Two brothers with acute nephritis were admitted to the hospital at about the same time. In another family, a father had recurrent nephritis, a son developed acute nephritis, and a daughter was found to have albuminuria. A third family of seven lived in a house consisting of one room, kitchen, scullery and lavatory. All three sons, ages 18,19 , and 20 years, were admitted to the hospital with acute nephritis within several weeks of each other. The urines of the father and of one daughter were examined, and the specimen from the daughter contained albumin.

\section{OCCURRENCE OF ACUTE GLOMERULONEPHRITIS FOLLOWING SCARLET FEVER}

It is generally accepted that glomerulonephritis occurring after scarlet fever has not been as common during the past several decades as in former years. Modern textbooks (26-28) state that nephritis rarely follows an attack of scarlet fever, whereas Osler (29) in 1914 observed that the attack rate of nephritis was 10 to 25 per cent.

McCrae (30) in 1913 remarked that nephritis followed scarlet fever in from 3 to 70 per cent of all cases. In a discussion of the frequency of postscarlatinal nephritis, Elwyn (31) referred to the figures of other authors : Rolley, 7 per cent; Weiss, 9 per cent ; Heubener, 10 to 20 per cent; and Jackman, 20 per cent. It would appear from these figures not only that glomerulonephritis was a fairly frequent complication of scarlet fever several decades ago, but also that the incidence of nephritis varied widely.

A number of clinicians recognized the variability in the occurrence of nephritis in patients with scarlet fever. Barr (32) in 1887 stated that nephritis occurred more frequently in some epidemics of scarlet fever than in others, thus altering the belief of a direct influence of the scarlet fever poison on the renal cells. Smith (33) remarked in 1892 that nephritis was a variable complication since West found albumin in the urine of only 4 per cent of patients with scarlet fever, whereas Atkinson observed some epidemics where albuminuria was noted in 70 per cent of patients. In 1909 Hunter 
TABLE I

Incidence of acute nephritis following scarlet fever

\begin{tabular}{|c|c|c|c|c|}
\hline Author & $\begin{array}{l}\text { Date } \\
\text { of } \\
\text { study }\end{array}$ & $\begin{array}{l}\text { Patients with } \\
\text { scarlet } \\
\text { fever }\end{array}$ & $\begin{array}{c}\text { Per cent } \\
\text { developing } \\
\text { nephritis }\end{array}$ & Remarks \\
\hline $\begin{array}{l}\text { Royer (40) } \\
\text { Wahrer (1) } \\
\text { Benedict (41) } \\
\text { Beatty (42) } \\
\text { McCrae (43) }\end{array}$ & $\begin{array}{l}1906 \\
1906 \\
1906 \\
1907 \\
1911\end{array}$ & $\begin{array}{c}526 \\
195 \\
\text { Unknown } \\
550 \\
850\end{array}$ & $\begin{array}{r}7.43 \\
18.0 \\
14.2 \\
3.1 \\
12.5\end{array}$ & $\begin{array}{l}\text { Includes cases of albuminuria with casts } \\
\text { Hemorrhagic nephritis } \\
\text { Five patients gave history of previous } \\
\text { nephritis }\end{array}$ \\
\hline $\begin{array}{l}\text { Dublin (44) } \\
\text { Fox and Gordon (45) } \\
\text { Kinloch, Smith, and Taylor (46) } \\
\text { Toomey and Dolch (47) } \\
\text { Wylie (48) } \\
\text { Gordon (49) } \\
\text { Toomey and Dolch (50) } \\
\text { Welford (51) } \\
\text { Lichtenstein (52) } \\
\text { Lucchesi and Bowman (53) }\end{array}$ & $\begin{array}{l}1916 \\
1923 \\
1923 \\
1926 \\
1927 \\
1927 \\
1928 \\
1928 \\
1929 \\
1929\end{array}$ & $\begin{array}{r}1,153 \\
1,000 \\
500 \\
1,658 \\
29 \\
367 \\
60 \\
275 \\
350 \\
2,332\end{array}$ & $\begin{array}{r}2.9 \\
1.2 \\
2.8 \\
2.4 \\
17.0 \\
4.0 \\
6.6 \\
3.3 \\
0.6 \\
1.2\end{array}$ & $\begin{array}{l}\text { Definite nephritis } \\
\text { Blood casts which persisted } \\
\text { Hemorrhagic nephritis }\end{array}$ \\
\hline $\begin{array}{l}\text { Veldee, Stevenson, and } \\
\text { Mitchell (54) } \\
\text { Bradford (55) } \\
\text { Benedict (41) } \\
\text { Hogarth (56) } \\
\text { Wesselhoeft and Smith (57) } \\
\text { Peters and Havard (58) } \\
\text { Sako, Dwan, and Platou (59) } \\
\text { de Waal (60) } \\
\text { Ulrich and Young (61) } \\
\text { Fox and Hardgrove (62) } \\
\text { Kodama and coworkers (63) } \\
\text { Ström (64) } \\
\text { French (65) } \\
\text { Gibel and Litvak (66) } \\
\text { Rascoff and Nussbaum (67) }\end{array}$ & $\begin{array}{l}1931 \\
1931 \\
1932 \\
1937 \\
1937 \\
1937 \\
1938 \\
1938 \\
1939 \\
1939 \\
1939 \\
1939 \\
1939 \\
1940 \\
1940\end{array}$ & $\begin{array}{r}82 \\
533 \\
741 \\
115 \\
100 \\
150 \\
100 \\
2,169 \\
96 \\
100 \\
65 \\
122 \\
170 \\
1,592 \\
42\end{array}$ & $\begin{array}{r}12.2 \\
4.5 \\
9.2 \\
0.9 \\
1.0 \\
3.3 \\
11.0 \\
0.4 \\
2.1 \\
2.0 \\
0 \\
0 \\
0 \\
0.6 \\
0\end{array}$ & $\begin{array}{l}134 \text { received serum } \\
\text { One-half not treated }\end{array}$ \\
\hline
\end{tabular}

(34) recorded that nephritis was a variable complication of scarlet fever.

More recently a number of investigators have commented on the fact that post-scarlatinal nephritis is less common than past experience dictated. In 1927 Campbell (35) showed that the incidence of acute nephritis following scarlet fever was not as high as it was usually considered to be, and, in fact, was then less than 3 per cent. Rolleston (36), in 1930, commented on the use of antitoxin in the treatment of scarlet fever, and stated that the frequency of nephritis had so diminished in the years immediately preceding the introduction of antitoxin that he was unwilling to regard the treatment as being in any way responsible. Seegal, Seegal, and Lyttle (37), in 1935, remarked that scarlet fever played a relatively minor role in initiating attacks of nephritis. Murphy, Grill, and Moxon (38) concluded that scarlet fever can no longer be looked upon as the chief cause of glomerulonephritis and Wesselhoeft (39), in 1941, stated that nephritis is actually an infrequent complication.
Data showing the reported attack rates of glomerulonephritis following scarlet fever are shown in Table I. Specific therapy was administered during the acute infection only where noted. Presumably all patients had routine urinalyses and were studied for approximately three weeks. The criteria for the diagnosis of nephritis in these studies varied considerably and in some instances were not recorded. For example, McCrae (43) included as cases of nephritis all patients with albumin or casts in the urine, whereas if only those patients are included who had either physical signs of nephritis, or red cells, albumin and casts in the urine, 2.7 per cent rather than 12.5 per cent of patients would have been so classified. In contrast, Wahrer (1) observed a group of 195 patients with scarlet fever, 35 of whom developed hemorrhagic nephritis. Thus even though standard criteria for diagnosis were not employed, it is apparent that there has been considerable variation in the attack rate of acute nephritis following scarlet fever.

A more accurate estimation of the degree of variation in the attack rate of nephritis following scar- 
TABLE II

Variations in incidence of nephritis following scarlet fever observed in four haspitals

\begin{tabular}{|c|c|c|c|}
\hline Author & Year & $\begin{array}{l}\text { Number of } \\
\text { cases of } \\
\text { scarlet fever }\end{array}$ & Nephritis \\
\hline Granrud (68) & $\begin{array}{l}1890 \\
1913 \\
1937 \\
1938 \\
1939 \\
1946\end{array}$ & $\begin{array}{r}668 \\
1,338 \\
259 \\
208 \\
1,298 \\
338\end{array}$ & $\begin{array}{c}\text { per cent } \\
7.2 \\
2.2 \\
3.5 \\
1.4 \\
2.6 \\
1.5\end{array}$ \\
\hline Hunter (34) & $\begin{array}{l}1904 \\
1905 \\
1906 \\
1907\end{array}$ & $\begin{array}{l}114 \\
135 \\
179 \\
220\end{array}$ & $\begin{array}{l}2.6 \\
0.7 \\
1.6 \\
5.0\end{array}$ \\
\hline $\begin{array}{l}\text { Joe and Williamson } \\
\text { (69) }\end{array}$ & $\begin{array}{l}1920 \\
1921 \\
1922 \\
1923 \\
1924 \\
1925\end{array}$ & $\begin{array}{l}z \\
z \\
z\end{array}$ & $\begin{array}{l}1.4 \\
2.7 \\
1.3 \\
2.1 \\
4.6 \\
4.9\end{array}$ \\
\hline $\begin{array}{l}\text { Peters and Cullum } \\
\text { (70) }\end{array}$ & $\begin{array}{l}1910-14 \\
1915-19 \\
1920-24 \\
1925-29 \\
1930-34 \\
1935-36\end{array}$ & $\begin{array}{l}2,771 \\
1,329 \\
2,496 \\
3,148 \\
2,427 \\
1,350\end{array}$ & $\begin{array}{l}1.9 \\
1.9 \\
2.5 \\
0.9 \\
0.4 \\
3.2\end{array}$ \\
\hline
\end{tabular}

let fever might be obtained from reports from single hospital units. Such data are presented in Table II. Here variations as great as ten-fold exist in the attack rates.

\section{RELATIONSHIP OF NEPHRITIS TO SEROLOGICAL TYPE OF STREPTOCOCCUS}

The above review of the reported incidence of acute glomerulonephritis indicates that epidemics of the disease have occurred in the past and that multiple cases have been observed in families whose medical history indicated no predisposition to the disease. In addition, the attack rate of nephritis has been shown to vary following scarlet fever.

The cause for such variations in attack rates and for the epidemic occurrence of nephritis is not known. Some authors (71) have suggested that nutritional factors in the host may account for variations in the incidence of nephritis. It would appear more logical, however, to postulate that differences in the infecting organism were responsible for variations in attack rates following scarlet fever and for epidemics of the disease. Since it is known that certain biological properties of group A streptococci appear to be correlated with the serological type of group A streptococcus (72), the literature was reviewed in order to determine whether or not certain types of streptococci were associated with acute glomerulonephritis.

Published data concerning the serological type of organism associated with late complications of streptococcal infections are difficult to interpret in most instances. In many studies (60,73-86) the serological identification of group A streptococci was performed by the agglutination (87) technique and in only a few (88-91) was the precipitin method (92) employed. The former method of recognition of serological types is subject to considerable difficulty and cross reactions are common, whereas the precipitin method is considered to be more reliable (93). In addition to the technical variations in the identification of the streptococci, detailed bacteriological observations of the complications frequently have been omitted so that the relationship is not always clear of the type of streptococcus, isolated during the illness, to the attack of nephritis.

Among the studies $(60,73-86)$ employing the agglutination technique for the identification of the serological type of streptococcus, the report of Ehinger (73) is of special interest. In this study the type of streptococcus obtained from patients with scarlet fever admitted to the hospital was correlated with various complications. In a group of 26 patients from whom type 31 streptococci were isolated, six or 23 per cent developed acute nephritis. Other types, including 1-7 and 11-13, were also isolated from patients with scarlet fever and only a few subsequently developed nephritis. In a group of 2,118 patients with scarlet fever, Kelsey and Scholes (74) observed 37 patients with nephritis. Type 2 streptococci were isolated from throat cultures taken either at the onset of scarlet fever or during the acute attack of nephritis. Type 2 was responsible for 65 per cent of the cases of scarlet fever in this study. Other authors $(76,79-81,83)$ have isolated type 2 streptococci during the illness preceding the onset of nephritis. In 1912 there were three large epidemics of septic sore throat in Boston, Baltimore and Chicago which were said to be followed by attacks of acute nephritis (94). It is of interest that a strain from the Boston and Chicago outbreak was classified recently as type 13 (85). No nephritis was observed following a large number of infections due to types $17(74,77)$ and $15(75)$. Type 
3 was rarely associated with nephritis $(60,73,76$, $78,81,82$ ).

Results of studies using the precipitin method for type identification show that 317 type 17 infections $(89,90)$ and 100 type 5 infections (91) were not followed by nephritis. McMillan (88) observed 7,800 patients with scarlet fever from whom types 17,3 , and 19 were commonly isolated and only 2 patients developed nephritis. The author does not state which type was associated with the nephritis.

Recently 2,366 young adult males with exudative tonsillitis or pharyngitis caused by group A streptococci have been followed for at least three weeks after the onset of the acute infection. Other than codeine for pain, these patients received no specific therapy. There was only 1 patient, infected with type 12 streptococci, who developed nephritis, an attack rate of .04 per cent (Table III).

The above observations again emphasize the variation in the attack rate of nephritis following streptococcal infections, and, in addition, suggest that some strains (types) may be more nephritogenic than other strains. Since the occurrence of nephritogenic strains of streptococci would explain the variations in the incidence of nephritis, a

TABLE III

Occurrence of nephritis in a group of 2,366 Group A streptococcal infections *

\begin{tabular}{crc}
\hline \hline Type & Cases & Nephritis \\
\hline NT $\dagger$ & 212 & 0 \\
1 & 196 & 0 \\
3 & 12 & 0 \\
4 & 5 & 0 \\
5 & 395 & 0 \\
6 & 96 & 0 \\
12 & 62 & 1 \\
14 & 1,103 & 0 \\
18 & 43 & 0 \\
19 & 1 & 0 \\
22 & 1 & 0 \\
23 & 2 & 0 \\
24 & 213 & 0 \\
25 & 1 & 0 \\
28 & 3 & 0 \\
30 & 7 & 0 \\
33 & 1 & 0 \\
39 & 2 & 0 \\
40 & 1 & 0 \\
41 & 5 & 0 \\
42 & 2 & 0 \\
43 & 2 & 0 \\
44 & 1 & 0
\end{tabular}

* The authors are indebted to the members of the Streptococcal Disease Laboratory, Warren Air Force Base, Wyoming, for supplying these data.

$\dagger$ Not typeable with the available antisera. study of the organism associated with initial attacks of this complication was undertaken.

Cultures of the tonsils and oropharynx were obtained from individuals with acute nephritis entering hospitals in Cleveland and other areas. In addition, cultures were obtained in many instances from members of the household living in intimate contact with the patient with nephritis. Organisms showing beta-hemolysis after incubation on blood agar plates were grouped and typed after the methods of Maxted (95) and Swift, Wilson and Lancefield (92).

A summary of the results obtained thus far is presented in Table IV.4 Nephritis occurred within a period of five days in a sister and brother in Pittsburgh (Cases 1A and 2A). A group A, type 12 streptococcus was isolated from the ear of patient $1 \mathrm{~A}$; a culture was not available from patient $2 \mathrm{~A}$. Case 3 was the only instance of acute nephritis observed among 2,366 untreated streptococcal infections studied at Warren Air Force Base, Wyoming (Table III). Type 12 streptococci were isolated from this patient's throat on five different occasions. On September 19, 1950, patient 5B entered the hospital because of red urine and swelling of the face. The patient had a skin infection from which a beta-hemolytic streptococcus was isolated, but the strain was discarded before typing could be accomplished. Five days later, on September 24, the father of this child was admitted with acute nephritis and a group A, type 12 streptococcus was isolated from the culture of the oropharynx. The same organism was also isolated from other members of the household, but the urine from these individuals was normal on one examination.

Patient 7 is of special interest since she and other members of the family had been under continuous observation since 1948 (98). Throughout this period weekly throat cultures had failed to show type 12 streptococci and semi-annual urine examinations were normal. In November, 1950, all individuals in the family acquired type 12 streptococci. Patient 7 developed classical acute glomerulonephritis. The remaining members of the family were immediately given small amounts of penicillin. The urines of each of the four other members of the family showed abnormal numbers

4 A preliminary report of this study has appeared elsewhere (96). 
TABLE IV

Serological type of streptococcus isolated from patients in an initial attack of acute nephritis over a four year period

\begin{tabular}{|c|c|c|c|c|c|c|c|c|}
\hline \multirow[b]{2}{*}{ Case } & \multirow{2}{*}{$\underset{\substack{\text { Date } \\
\text { meath/ }}}{\text { year }}$} & \multirow[b]{2}{*}{ Location } & \multirow[b]{2}{*}{ Age } & \multicolumn{2}{|c|}{ Urine } & \multicolumn{2}{|c|}{ Physical examination } & \multirow{2}{*}{$\begin{array}{l}\text { Type } \\
\text { group A } \\
\text { strepto- } \\
\text { coccus }\end{array}$} \\
\hline & & & & $\begin{array}{l}\text { Hema- } \\
\text { turia }\end{array}$ & $\begin{array}{c}\text { Albumi- } \\
\text { nuria }\end{array}$ & $\begin{array}{l}\text { Blood } \\
\text { pressure }\end{array}$ & Edema & \\
\hline $\begin{array}{l}1 \mathrm{~A} \\
2 \mathrm{~A} \\
3 \\
4 \mathrm{~B} \\
5 \mathrm{~B} \\
6 \\
7\end{array}$ & $\begin{array}{r}3 / 49 \\
3 / 49 \\
5 / 50 \\
9 / 50 \\
9 / 50 \\
10 / 50 \\
11 / 50\end{array}$ & $\begin{array}{l}\text { Pittsburgh, Pa. } \\
\text { Pittsburgh, Pa. } \\
\text { Cheyenne, Wyo. } \\
\text { Cleveland, O. } \\
\text { Cleveland, O. } \\
\text { Cleveland, O. } \\
\text { Cleveland, O. }\end{array}$ & $\begin{array}{r}6 \\
8 \\
19 \\
32 \\
11 \\
35 \\
4\end{array}$ & & & $\begin{array}{l}84 / 56 \\
114 / 76 \\
220 / 160 \\
190 / 120 \\
170 / 125 \\
140 / 100 \\
132 / 56\end{array}$ & $\begin{array}{c}++ \\
++ \\
+ \\
0 \\
+ \\
+\end{array}$ & $\begin{array}{l}\frac{12}{12} \\
\frac{12}{12} \\
12\end{array}$ \\
\hline
\end{tabular}

\begin{tabular}{|c|c|c|c|c|c|c|c|}
\hline $\begin{array}{r}12 \\
8 \\
13 \\
9\end{array}$ & $\begin{array}{l}7 / 51 \\
2 / 51 \\
2 / 51 \\
3 / 51\end{array}$ & $\begin{array}{l}\text { Cleveland, O } \\
\text { Cleveland, O. } \\
\text { Rochester, N. Y. } \\
\text { Cleveland, O. }\end{array}$ & $\begin{array}{c}15 \\
15 \\
\text { Adult } \\
46\end{array}$ & $++t$ & $\underset{++}{+t}+$ & $\begin{array}{l}175 / 115 \\
132 / 82 \\
180 / 110 \\
175 / 102\end{array}$ & $\begin{array}{c}++ \\
+ \\
++ \\
++t\end{array}$ \\
\hline $\begin{array}{l}10 \\
11 \\
18 \\
19\end{array}$ & $\begin{array}{l}4 / 51 \\
4 / 51 \\
8 / 51 \\
1 / 51\end{array}$ & $\begin{array}{l}\text { Panama City, Fla. } \\
\text { Cleveland, O. } \\
\text { Cleveland, O. } \\
\text { Hawaii }\end{array}$ & $\begin{array}{r}8 \\
5 \\
4 \\
11\end{array}$ & & & $\begin{array}{l}154 / 100 \\
118 / 85 \\
105 / 68 \\
200 / 140\end{array}$ & $\frac{+}{+}$ \\
\hline 20 & $\begin{array}{r}1 / 51 \\
12 / 51\end{array}$ & $\begin{array}{l}\text { Hawaii } \\
\text { Cleveland, } 0 .\end{array}$ & $\begin{array}{r}5 \\
27\end{array}$ & + & $\stackrel{t}{+t}$ & $\begin{array}{l}160 / 124 \\
140 / 108\end{array}$ & $\begin{array}{l}+ \\
+\end{array}$ \\
\hline
\end{tabular}

\begin{tabular}{|c|c|c|c|c|c|c|c|}
\hline $\begin{array}{l}21 \\
22 \\
23\end{array}$ & $\begin{array}{l}3 / 52 \\
3 / 52 \\
3 / 52\end{array}$ & $\begin{array}{l}\text { Syracuse, N. Y. } \\
\text { Syracuse, N. Y. } \\
\text { Syracuse, N. Y. }\end{array}$ & $\begin{array}{r}15 \\
2 \\
35\end{array}$ & & & $\begin{array}{l}+* \\
+^{*} \\
t^{*}\end{array}$ & \\
\hline $\begin{array}{l}24 \\
25 \\
15 \\
16\end{array}$ & $\begin{array}{l}4 / 52 \\
4 / 52 \\
4 / 52 \\
4 / 52\end{array}$ & $\begin{array}{l}\text { Syracuse, N. Y. } \\
\text { Syracuse, N. Y. } \\
\text { Cleveland, O. } \\
\text { Cleveland, O. }\end{array}$ & $\begin{array}{r}7 \\
10 \\
2 \\
15\end{array}$ & & & $\begin{array}{c}t^{*} \\
t^{*} \\
90 / 60 \\
160 / 90\end{array}$ & + \\
\hline 17 & $4 / 52$ & Cleveland, 0. & 11 & $+t+t$ & $+t+t$ & $144 / 90$ & 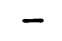 \\
\hline 26 & $\begin{array}{l}4 / 52 \\
5 / 52\end{array}$ & $\begin{array}{l}\text { Cleveland, } \mathrm{O} . \\
\text { Bainbridge, Md. }\end{array}$ & $\begin{array}{l}37 \\
20\end{array}$ & 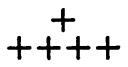 & $\begin{array}{c}+t \\
+t+t\end{array}$ & $\begin{array}{l}150 / 100 \\
160 / 114\end{array}$ & + \\
\hline
\end{tabular}

Has one child with history of puffy eyes at same time.

Cases 19 and 20 occurred as part of epidemic in Hawaii.

Cultures of wife, three children, and playmate all showed type 12. single urine specimens negative.

Type 12 isolated from son.

Type 12 from brother.

Type 12 isolated from mother and sister.

Type 12 is also isolated from mother.

Type 4 from son.

One example of a large epidemic of acute nephritisamong military personnel caused by type 12 (97).

\begin{tabular}{|c|c|c|c|c|c|c|c|}
\hline 28 & $5 / 52$ & Cleveland, 0. & 3 & $+t+t$ & $+t+t$ & $140 / ?$ & + \\
\hline 29 & $6 / 52$ & Syracuse, N. Y. & 5 & $t^{*}$ & $+*$ & $t^{*}$ & $t^{*}$ \\
\hline $\begin{array}{l}30 \\
31 \\
32 \mathrm{C} \\
33 \mathrm{C}\end{array}$ & $\begin{array}{l}7 / 52 \\
9 / 52 \\
9 / 52 \\
9 / 52\end{array}$ & $\begin{array}{l}\text { Cleveland, O. } \\
\text { Cleveland, O. } \\
\text { Cheyenne, Wyo. } \\
\text { Cheyenne, Wyo. }\end{array}$ & $\begin{array}{r}4 \\
14 \\
5 \\
3\end{array}$ & & $\begin{array}{c}+ \\
+++ \\
+ \\
+\end{array}$ & $\begin{array}{l}152 / 100 \\
140 / 100 \\
160 / 100 \\
130 / 90\end{array}$ & $\begin{array}{l}+ \\
0 \\
+ \\
+\end{array}$ \\
\hline
\end{tabular}

Type 12 from brother, a nontypeable strain from another brother.

Had several attacks of sore throat before onset of nephritis.

Brother of patient 33C.

* Considered present and abnormal, degree not known.

The authors are grateful to many physicians who assisted in collecting these data. The data and specimens on the following cases were collected by Drs. T. S. Danowski (Cases 1A, 2A), L. P. Longley (Case 6), R. F. Jacox (Case 13), C. R. Benton (Case 10), D. Cho Choy (Cases 19, 20), H. A. Feldman (Cases 21-25, 29), M. Klaus (Cases 15, 17, 28), and S. R. Inkley (Case 26). 
of red cells, but none developed symptoms of nephritis.

During February, 1951, a strain of group A, type 12 streptococci was isolated from a patient in Rochester, New York (Case 13) by Dr. Ralph F. Jacox. The first non-type 12 strain was isolated from a throat culture of a girl, age 15 (Case 8). In this instance the strain was identified as type 4. Another type 4 organism was isolated from a small child in Panama City, Florida (Case 10). In Case 18, a type 4 streptococcus was isolated several months after the onset of an acute attack of nephritis. Whether this organism was related to the initial attack is unknown. The patient was discharged from the hospital one month previously for convalescence from an attack of acute nephritis. Two weeks before the present admission the child developed a cough and enlarged cervical lymph nodes. At the time of admission the mother observed red urine. Cultures on admission showed type 4 streptococci. ${ }^{5}$

Case 9 is interesting because there may have been another instance of nephritis in the same family. This patient is a father of five children. One child had a respiratory infection at the same time as the father, and about two days before the father developed periorbital edema, the child had swelling of the face and of the tissues around the eyes. This child was not available for examination, but it seems probable that he also had nephritis. $\mathrm{Pa}$ tients $32 \mathrm{C}$ and $33 \mathrm{C}$ are a brother and sister who developed acute nephritis within one week of each other. Although streptococci were not isolated from $32 \mathrm{C}$, type 12 streptococci were obtained in large numbers from the nose and throat of patient 33C.

During January and February, 1951, 43 patients with acute nephritis were admitted to two hospitals in Hawaii, whereas during the same period in 1949 and 1950 only 9 and 5 patients, respectively, were so diagnosed. Cultures from 2 patients (Case 19 and 20) obtained during the epidemic period in 1951 showed type 18 streptococci. Patient 14 showed type 12 streptococci on culture, as did the

One other type 4 streptococcus was received from Dr. Albert Dorfman, Chicago, from a collection of strains of Dr. Horace Gezon. This strain was from a member of the family where multiple cases of acute nephritis occurred (22). Since details of the strain are lacking, this patient is not included in Table IV. wife, three children and a playmate of the children. A single urine specimen from these carriers of type 12 streptococci failed to show albumin or red cells. Patient 27 represents only one patient of an epidemic of type 12 infections that resulted in over 100 cases of nephritis (97). There were 5 patients in Syracuse from whom type 12 streptococci were isolated and 1 patient (Case 29) who harbored type 25 .

The data presented in Table IV show that during the past four years type 12, and occasionally types 4 and 25 streptococci have been associated with attacks of acute nephritis in this country. In addition, type 18 streptococci were isolated from 2 patients with nephritis from an outbreak occurring in Hawaii. The facts that in several instances multiple cases have occurred in a single family unit, and that in one family (Case 7) all individuals developed hematuria following infection, suggest that type 12 was especially nephritogenic.

If a relation exists between acute nephritis and specific strains or types of streptococci, then such streptococci should be present in areas where nephritis occurs and absent in areas where there is no nephritis. In Cleveland, where most of the sporadic cases of nephritis were studied, the results of weekly cultures were available over a three year period through 1951 from a population of 260 people. This population was widely scattered throughout the eastern suburbs of Cleveland and included all members of approximately 60 families (98). During this three year period type 12 streptococci accounted for 17 per cent of the acquisitions of group A streptococci. There was a total of 66 type 12 acquisitions. Five of these acquisitions were followed by urinary complications : one individual developed symptoms of nephritis, and four others in the same family developed hematuria. The data from this sample of the population indicate that 83 per cent of all streptococcal infections in this area were due to types other than 12, and yet nephritis was associated with the type 12 infections. In Syracuse, Feldman (99) reported that type 12 infections were common in 1952 and at least 30 cases of nephritis were observed in the local hospitals during that wintera most unusual record for the community.

In contrast to the relatively frequent occurrence of nephritis in Cleveland and Syracuse is the absence of this complication among military popula- 
tions infected with group A streptococci. In a group of 2,304 infections caused by types other than 12 , there were no cases of nephritis. In a group of 62 type 12 infections in the same population, one patient developed nephritis.

The final evidence required to establish the hypothesis presented here would be to demonstrate that infection with one of these nephritogenic strains results in a higher attack rate of nephritis than when infection is caused by another type. To date, only two epidemics of nephritis have been reported in which serological typing was attempted. Kempe, Olmsted and Curnen (100) observed four boys who developed acute glomerulonephritis at about the same time. These patients were among a group of 34 boys in the second form of a boys' school. The total number of boys found to have hematuria in this group was 12 , or 35 per cent. Among the group of 34 , four were found to harbor beta-hemolytic streptococci ; group A, type 12 streptococcus was isolated from two individuals, the other two strains were not grouped or typed. The only other typeable strain isolated from boys in other forms in the school was type 12 . These data would tend to implicate type 12 as the cause of the epidemic of nephritis, and furthermore would indicate that the attack rate of nephritis was high.

A recent report from Australia (101) indicates that type 12 streptococci may be responsible for an outbreak of nephritis in that country. Eight cases of classical acute nephritis and 30 to $40 \mathrm{pa}$ tients with edema and albuminuria were observed in a town of 8,000 people located northwest of Melbourne. A survey of the bacterial flora of the throat showed that of 35 typeable group A streptococci isolated, 16 were type 12,10 type 22 , and 9 belonged to other types.

Since the institution of the present study three other epidemics of nephritis have been reported to the authors. Langmuir, Richardson, and Perry (102) observed 4 cases of acute glomerulonephritis among 311 pupils in a rural school in Harford County, Maryland. These cases occurred between March 2 and 25, 1949. Throat cultures were obtained and of 46 group A strains, 34 or 74 per cent were type 12 . In one of the families of a patient with nephritis, type 12 was isolated from the throat culture of a sibling. Denny and Thomas (103) studied an outbreak of 2 cases of acute nephritis which occurred in a grade school in Min- nesota. In this school there were approximately 300 students; cultures of the throat were obtained from 56. There were seven group A strains and one group $\mathrm{C}$ strain isolated. The group A streptococci included three type 12 strains, one type 6 , and three strains which were not typeable with the available sera. Streptococci were not isolated from the two patients with nephritis, both of whom had received penicillin.

An epidemic of acute nephritis involving 5 and possibly 6 of 10 siblings in Rochester was studied in 1947 by Martin (24). Although beta-hemolytic streptococci were isolated from four of the patients with nephritis, they were not classified serologically. However, a type 12 streptococcus was isolated from a culture obtained from an older sibling.

These five outbreaks of acute glomerulonephritis occurring in widely separated areas (Connecticut, Maryland, Minnesota, New York, and Australia) were apparently associated with type 12 infections. It is impossible, however, to establish an attack rate from these data. More recently, there has been a large outbreak of over 100 cases of nephritis in a military population (97). In this outbreak it was possible to study all streptococcal infections and the results to be reported elsewhere (97) will establish that certain strains of type 12 streptococci are indeed associated with a high attack rate of nephritis.

\section{DISCUSSION}

The existence of either a rheumatogenic (104) or a nephritogenic $(96,105)$ strain of streptococci has been postulated. Although there is some evidence that one strain of group A streptococci lacked rheumatogenic capacities (106) whereas infection with another resulted in a high attack rate of rheumatic fever (104), most of the data indicate that various typeable strains of group A streptococci do not vary in their ability to produce rheumatic fever (107). In general, approximately 3 per cent of streptococcal infections are followed by an attack of rheumatic fever (107).

The incidence of rheumatic fever in various population groups should reflect the number of streptococcal infections occurring in that population, since the attack rate of rheumatic fever is relatively constant following such infections. The attack rate of rheumatic fever following streptococcal infections is not altered appreciably by such 
factors as climate, geographical area, and age (107). Several studies $(108,109)$ have shown that rheumatic and scarlet fever, each a manifestation of a group A streptococcal infection, are more common in the northern than in the southern latitudes of North America. Acute nephritis, however, appears to be as common in the south as in the northern states of this country (108). Although the effect of climate on the individual infected with group A streptococci may account for altered susceptibility to nephritis as compared to rheumatic fever, it would appear more likely that the strains of streptococci responsible for the illness preceding these two complications varied in their ability to produce nephritis. Thus, the data of Seegal, Seegal and Jost (108) show that in the hospitals studied, the number of admissions for acute nephritis had little relationship to the number of rheumatic admissions. For example, at the Vancouver General Hospital in 1917 there were 145 cases of rheumatic fever and 29 cases of acute nephritis; the following year there were only 23 cases of rheumatic fever and 26 cases of nephritis. Here in a single geographical area there appeared to be little relationship between the number of cases of nephritis and rheumatic fever.

The impression that the incidence of acute nephritis following scarlet fever has decreased in the past several decades is partially confirmed by the data presented. More impressive than the decline in the attack rate of this complication are the remarkable variations in the incidence of nephritis recorded during the period surveyed. Although some of this variation is undoubtedly due to criteria of diagnosis and frequency of observations, it is believed that many of the differences are significant. In the present study of 2,366 patients with exudative tonsillitis and pharyngitis from whom group A streptococci were isolated, there was only one patient who developed symptoms of nephritis. All these patients were examined at least three weeks after the onset of the streptococcal infection for which they received no specific form of therapy. In contrast to these results is the attack rate of 18 per cent observed by Wahrer (1), a 450-fold difference! This extreme variability in the attack rates of acute nephritis following known streptococcal infections suggests that nephritogenic strains of streptococci may exist.

The epidemic occurrence of nephritis in various populations, especially within the family unit, could be explained by infection with nephritogenic organisms. It has been suggested that the occurrence of multiple cases within the family unit may be due to some factor, genetic or otherwise, that predisposes the members to this disease (13). If such is the case, these factors have not been defined. Since it is known that respiratory infections spread readily when introduced into a family unit (98), it would seem reasonable to expect multiple cases of nephritis relatively frequently if strains of streptococci with marked nephritogenic capacities were introduced into such a population. In the present study a number of such family epidemics was observed, and it is likely that additional instances of nephritis would have been recorded if each family had been studied carefully.

The sudden appearance of nephritis in large population groups has been thought to be due to poor nutrition (71). It is exceedingly difficult to believe that inadequate nutrition was responsible for the outbreaks of nephritis which occurred in private and public schools and among military personnel reviewed in this report. Likewise, it is doubtful that nutrition played a role in the large epidemic of nephritis which was observed during World War I.

It is commonly believed that the form of the clinical disease produced by group A streptococci is not a function of the serological type. Although this is generally true, it has been demonstrated that during short periods of time, when there are several serological types producing disease in a given population, one type may result in a higher attack rate of scarlet fever than another type (110). Furthermore, it is known that certain biological characteristics of streptococci can be correlated roughly with the serological type $(72,86)$. Thus, it appears possible that the complication, nephritis, might be associated with strains belonging to certain serological types.

A review of the literature failed to show that nephritis was caused by only one or a few serological types, although Ehinger (73) reported that type 31 appeared to be responsible for 6 cases of nephritis out of 26 infected with this organism. In most of these studies typing was performed by the agglutination or Griffith technique (87) which experience has shown not to be as reliable as the precipitin method (92). Furthermore, many of 
these bacteriological studies were performed in contagious disease hospitals where cross infections are not uncommon, so that complications such as nephritis may not have been due to the type isolated during the acute phase of the streptococcal infection. The fact that 1,103 type 14 infections were observed without a single instance of nephritis indicates, at least, that this type during the period of observation was not associated with nephritis.

At the time the present study was instituted only a limited population which could be followed from the onset of the acute streptococcal infection to the onset of nephritis was available. As a result, patients with nephritis entering the hospital were also used as a source of bacteriological material. In these hospitalized patients cultures were obtained soon after admission so that cross infections with new types were unlikely. Furthermore, cultures obtained from parents and siblings in the home frequently showed streptococci of a similar type to the one isolated from the patient with nephritis.

In the present study it is apparent that type 12 streptococci appeared to be related to nephritis in the majority of patients ( 84 per cent) even though the patients were studied over a four year period in various sections of this country. In addition to these observations Wright (111) reports the isolation of type 12 streptococci from 3 patients with acute nephritis in the Chicago area. Wertheim and his coworkers (112) have made the interesting observation that of 39 typeable group A cultures isolated from patients with acute nephritis during 1936 to 1942 in New York City, 20 or 51 per cent, were type 12. Rantz (113) recently reported the Griffith types of streptococci isolated from 84 patients with otitis media studied between 1939 and 1943 in the San Francisco area. Type 12 streptococci were isolated from the exudate obtained from the middle ear in 14 patients and two of these individuals subsequently developed acute hemorrhagic Bright's disease. A third patient with otitis media developed nephritis, but the organism was not identified serologically. One patient who had otitis media due to type 1 streptococci was found to have latent nephritis a year later.

Although these observations establish that infections with type 12 and type 4 streptococci may result in an attack of acute nephritis, they do not indicate the magnitude of the attack rate. The data presented by Kempe, Olmsted and Curnen (100) would indicate that the streptococcus (presumably type 12) that caused the epidemic in Connecticut was indeed markedly nephritogenic. In contrast, the 62 type 12 infections in Wyoming were not associated with a high attack rate. Studies to be reported elsewhere (97) will show that in a large epidemic of nephritis occurring in the spring of 1952 , the infecting strain, type 12 , was associated with a high incidence of complications. These data would indicate that there may be straindifferences within organisms belonging to type $12 .^{\circ}$

These data are of some importance from both a practical and theoretical viewpoint. Because of the existence of nephritogenic strains, the family and other population units from which a patient with nephritis comes should be observed for evidence of other apparent and inapparent cases of the disease. In order to prevent spread of the disease, an attempt should be made to eradicate the organism from all carriers in such populations. It is possible that individuals who have been infected with a nephritogenic strain are subsequently immune to that serological type, since there is evidence that immunity to streptococcal infections in man is type-specific (115). Thus the chances of developing a second attack of acute nephritis should be exceedingly small since the number of types responsible for this complication is few.

By the experimental use of streptococci derived from patients with acute nephritis, and especially organisms isolated from cases during epidemics, the pathogenesis of glomerulonephritis may be elucidated. Thus far attempts to reproduce the disease in monkeys and rabbits have failed (116).

\section{CONCLUSIONS}

A review of the literature has demonstrated that the attack rate of acute glomerulonephritis following streptococcal infections varies from year to year. Furthermore, epidemics of nephritis have been observed in family units and other population groups. The cause for the variations in the

- It is known (114) that type 12 streptococci as determined by the precipitin technique include two serologically distinct types (types 10 and 12) when tested by the Griffith technique. 
attack rates of acute nephritis following streptococcal infections appears to be due to varying nephritogenic capacities of the infecting organism.

In a group of 31 patients with acute nephritis observed during a four year period in various cities in this country, type 12 streptococci were associated with 26 attacks. Streptococci of types 4 and 25 were related to four and one attacks of nephritis, respectively. Type 18 streptococci were isolated from 2 patients with nephritis observed during an outbreak of this disease in Hawaii.

The data presented demonstrate that infection with type 12 and perhaps type 4 streptococci is especially likely to be followed by an attack of acute glomerulonephritis. Some evidence was obtained which indicated that strains of type 12 may vary in their nephritogenic capacity.

\section{ACKNOWLEDGMENTS}

The authors wish to thank Miss Margaret M. Hezebicks for assistance in these studies. Typing and grouping sera were obtained through the New York Department of Health, the Army Medical School, and the Communicable Disease Center, U.S.P.H.S.

\section{REFERENCES}

1. Wahrer, C. F., An epidemic of hemorrhagic nephritis following scarlet fever. J. A. M. A., 1908, 51, 1410.

2. Brown, L., In discussion, Epidemic Nephritis (Meeting, Medical Society of London, Nov. 13, 1916). Brit. M. J., 1916, 2, 723.

3. Brown, W. L., Report on fifty-eight cases of acute nephritis occurring in soldiers of the expeditionary force, investigated at St. Bartholomew's Hospital for the Medical Research Committee. J. Roy. Army M. Corps, 1915, 25, 75.

4. Evans, G., Trench nephritis (war nephritis). M. Press, 1941, 206, 68.

5. Peace, P. C., Nephritis following tonsillitis. Brit. M. J., 1926, 1, 17.

6. Molony, C. B., An account of an unusual mental hospital epidemic. J. Ment. Sc., 1927, 73, 397.

7. Formijne, P., On an epidemic of acute glomerulonephritis in Amsterdam. Acta med. Scandinav., 1948, 129, 509.

8. Klein, J., Acute glomerulo-nephritis. Acta med. Scandinav., 1947, 129, 156.

9. Fleming, J., An epidemic of acute nephritis. Lancet, 1949, 1, 763.

10. Brod, J., Acute diffuse glomerulonephritis. Am. J. Med., 1949, 7, 317.

11. Pratas, S., Glomérulo-nefrite difusa aguda epidemica. Amatus Lusitanus, 1944, 3, 559.
12. Cascalea, M. C., Arias, C., and Parada, J. F., Nefritis epidémica. Medicina (Buenos Aires), 1945, 6, 21.

13. Addis, T., Glomerular Nephritis. Diagnosis and Treatment. Macmillan, New York, 1948.

14. Thomson, W. W. D., and MaCauley, H. F., Influenza as an aetiological factor in nephritis, with an account of four cases of post-influenza nephritis in the same family. Lancet, 1920, 1, 481.

15. Hill, L. W., Studies in the nephritis of children. Clinical considerations of classification, etiology, prognosis and treatment. Am. J. Dis. Child., 1919, $17,270$.

16. Ernstene, A. C., and Robb, G. P., A familial epidemic of acute glomerulonephritis. Relation to the pathogenesis of the disease. J. A. M. A., 1931, 97, 1382.

17. Schuricht, F., Zur Frage der familiären Disposition zu Nierenkomplikationen bei Scharlach. Kinderärztliche Praxis, 1936, 7, 539.

18. Ellenberg, S. L., and Martin, A. T., Acute nephritis simultaneously affecting three siblings. Arch. Pediat., 1940, 57, 38.

19. Rinkoff, S. S., Stern, A., and Schumer, H., Familial nephritis. Report of cases and review of the literature. J. A. M. A., 1939, 113, 661.

20. Tudor, R. B., Acute glomerulonephritis occurring in three children in same family. Am. J. Dis. Child., $1943,66,528$.

21. Kilpatrick, L. G., Susceptibility to acute nephritis. Brit. M. J., 1945, 1, 222.

22. Gezon, H., Personal communication.

23. Spink, W. W., Personal communication.

24. Martin, F. J., Personal communication.

25. Eason, J., Smith, G. L. M., and Buchanan, G., Heredity and familial nephritis. Lancet, 1924, 2, 639.

26. Bradford, W. L., in Mitchell-Nelson, Textbook of Pediatrics. W. B. Saunders, Philadelphia, 1950, 5 th ed., page 478.

27. Rantz, L. A., in Cecil, R. L., and Loeb, R. F., A Textbook of Medicine. W. B. Saunders, Philadelphia, 1951, 8th ed., page 148.

28. Top, F. H., and collaborators, Handbook of Communicable Diseases. C. V. Mosby, St. Louis, 1947, 2nd ed.

29. Osler, W., The Principles and Practice of Medicine. Appleton, New York, 1912, 8th ed., page 341.

30. McCrae, J., The incidence of nephritis after scarlet fever. Tr. A. Am. Physicians, 1913, 28, 194.

31. Elwyn, H., Nephritis. Macmillan, New York, 1926.

32. Barr, J., Post-scarlatinal nephritis. Arch. Pediat., $1887,4,449$.

33. Smith, J. L., Scarlatinal nephritis. Arch. Pediat., 1892, 9, 241.

34. Hunter, W., The complications of scarlet fever. Practitioner, 1909, 82, 1.

35. Campbell, D. G., An address on the relationship between scarlet fever and chronic nephritis. Canad. M. A. J., 1927, 17, 779. 
36. Rolleston, J. D., The antitoxin treatment of scarlet fever. Practitioner, 1930, 125, 236.

37. Seegal, D., Seegal, B. C., and Lyttle, J. D., The nature of the preceding infection in acute glomerulonephritis in two New York hospitals and in four southern hospitals. J. A. M. A., 1935, 105, 17.

38. Murphy, F. D., Grill, J., and Moxon, G. F., Acute diffuse glomerular nephritis. Study of ninety-four cases with special consideration of the stage of transition into the chronic form. Arch. Int. Med., 1934, 54, 483.

39. Wesselhoeft, C., Nephritis in scarlet fever and its treatment. J. A. M. A., 1941, 116, 36.

40. Royer, B. F., An analysis of the kidney condition of eight hundred cases of scarlet fever treated with routine doses of chloral hydrate: the analysis contrasted with seven hundred fifty-six cases having the usual remedies. Penn. M. J., 1906, 10, 286.

41. Benedict, H., Bemerkungen zu einer Scharlachstatistik de Jahres 1932. Wien. klin. Wchnschr., 1933, 46, 869.

42. Beatty, R. P., A study of the complications arising in five hundred and fifty consecutive cases of scarlet fever treated at the Grove Hospital, Tooting, London, S. W. Dublin J. M. Sc., 1907, 123, 11.

43. McCrae, J., A study of eight hundred and fifty cases of scarlet fever with a more particular consideration of seventy-one fatal cases. Canad. M. A. J., 1911, 1, 293.

44. Dublin, L. I., A study of 1,153 cases of scarlet fever with special reference to their sequelae. J. A. M. A., 1916, 66, 1667.

45. Fox, M. J., and Gordon, N. F., Treatment of scarlet fever. Arch. Int. Med., 1944, 74, 1.

46. Kinloch, J. P., Smith, J., and Taylor, J. S., The newer knowledge of diphtheria and scarlet fever and its application in hospital practice and in community immunization. J. Hyg., 1927, 26, 327.

47. Toomey, J. A., and Dolch, E. G., Studies in scarlet fever. III. An analysis of scarlet fever cases untreated by specific serums or antitoxins. Am. J. Dis. Child., 1927, 33, 424.

48. Wylie, M. E., Serum treatment of scarlatina. J. Hyg., 1930, 30, 331.

49. Gordon, J. E., Treatment of scarlet fever with streptococcus antitoxin. J. A. M. A., 1927, 88, 382.

50. Toomey, J. A., and Dolch, E. G., Scarlet fever. VI. The use of scarlet fever antitoxins. Am. J. Dis. Child., 1928, 36, 1173.

51. Welford, N. T., The use of scarlet fever antitoxin. Am. J. Dis. Child., 1929, 37, 553.

52. Lichenstein, A., Studies in scarlet fever. VII. Treatment with streptococcus antitoxic serum. Acta Paediat., 1931, 10, 549.

53. Lucchesi, P. F., and Bowman, J. E., Antitoxin versus no antitoxin in scarlet fever. J. A. M. A., 1934, 103, 1049.

54. Veldee, M. V., Stevenson, F. E., and Mitchell, A. G., Scarlet-fever streptococcus antitoxin in the treat- ment of scarlet fever. Pub. Health Rep., 1931, 46, 3023.

55. Bradford, W. L., Tonsillectomy. Its effect on the incidence, severity and complications of scarlet fever and on the number of hemolytic streptococci in the throat. Am. J. Dis. Child., 1932, 44, 279.

56. Hogarth, J. C., Para-benzylaminobenzenesulphonamide in the treatment of scarlet fever. Brit. M. J., $1937,2,1160$.

57. Wesselhoeft, C., and Smith, E. C., The use of sulfanilamide in scarlet fever. New England J. Med., 1938, 219, 947.

58. Peters, B. A., and Havard, R. V., Chemotherapy of streptococcal infections with $p$-benzylamino-benzene-sulphonamide. Lancet, 1937, 1, 1273.

59. Sako, W., Dwan, P. F., and Platou, E. S., Sulfanilamide and serum in the treatment and prophylaxis of scarlet fever. J. A. M. A., 1938, 111, 995.

60. de Waal, H. L., The serological types of haemolytic streptococci in relation to the epidemiology of scarlet fever and its complications. J. Hyg., 1940, 40, 172.

61. Ulrich, H. J., and Young, T. R., Sulfanilamide and complications of scarlet fever. J. Missouri M. A., 1939, 36, 445.

62. Fox, M., and Hardgrove, M., Scarlet fever therapy. A comparison of convalescent serum and sulphanilamide. Am. J. Med. Sc., 1940, n.s., 199, 495.

63. Kodama, T., Ozaki, M., Nisiyama, S., Igarasi, J., Tiku, Y., and Kawamura, H., The serological grouping and typing of the hemolytic streptococci isolated in Tokyo. III. Kitasato Arch. Exper. Med., 1939, 16, 110.

64. Ström, J., Prontosil rubrum bei Behandlung von Scharlach. Acta. Paediat., 1939, 23, 333.

65. French, J. O., The sulphanilamide treatment of scarlet fever. J. Hyg., 1939, 39, 581.

66. Gibel, H., and Litvak, A. M., An analysis of 1,592 cases of scarlet fever, from August 1939 to July 1940, at Kingston Avenue Hospital, Brooklyn, New York. Arch. Pediat., 1941, 58, 597.

67. Rascoff, H., and Nussbaum, S., Therapeutic procedures for scarlet fever. Comparative studies. Am. J. Dis. Child., 1940, 60, 552.

68. Granrud, H. B., Complications of scarlet fever in Oslo during the period 1890-1947. Acta paediat., 1949, 37, 163.

69. Joe, A., and Williamson, A. B., A note on a severe type of scarlatinal nephritis. Edinburgh Med. J., 1926, 33, 49.

70. Peters, B. A., and Cullum, I. M., Postscarlatinal nephritis; a study in prevention. Brit. M. J., 1937, 1, 1020.

71. Waugh, D., and More, R. H., Experimental globulin glomerulonephritis in rabbits. Morphological and functional changes. J. Exper. Med., 1952, 95, 555.

72. Commission on Acute Respiratory Diseases, Studies on streptococcal fibrinolysis. V. The in vitro pro- 
duction of fibrinolysin by various groups and types of beta-hemolytic streptococci; relationship to antifibrinolysin production. J. Exper. Med., 1947, 85, 441.

73. Ehinger, A., On the haemolytic streptococci in scarlet fever. Studies on the epidemiology and clinical course of scarlet fever on the basis of typings of streptococci, with special reference to certain complications. Acta med. Scandinav., 1945, Supp., 156, 1.

74. Kelsey, H., with commentary by Scholes, F. V., Streptococcal types in scarlet fever: the association of change of streptococcal type with complications. M. J. Australia, 1941, 1, 728.

75. Bloomfield, A. L., and Rantz, L. A., An outbreak of streptococcic septic sore throat in an army camp. Clinical and epidemiologic observations. J. A. M. A., 1943, 121, 315.

76. Burton, A. H. G., and Balmain, A. R., Scarlet fever. Some aspects of bacteriology and serum treatment. Lancet, 1929, 2, 545.

77. Henningsen, E. J., and Ernst, J., Milk epidemic of angina, originating from a cow with mastitis and due to streptococcus pyogenes (Lancefield group A). J. Hyg., 1938, 38, 384.

78. Henningsen, E. J., and Ernst, J., Milk epidemic of scarlet fever and angina, originating from a milkmaid with scarlatinal otitis media. J. Hyg., 1939, 39, 51.

79. Kodama, T., Ozaki, M., Nishiyama, S., and Chiku, $Y$., The serological grouping and typing of the hemolytic streptococci isolated in Tokyo. II. Kitasato Arch. Exper. Med., 1938, 15, 162.

80. Camps, F. E., and Wood, J. L. M., An outbreak of epidemic sore throat of milk-borne origin. Lancet, 1936, 2, 756.

81. Gunn, W., and Griffith, F., Bacteriological and clinical study of one hundred cases of scarlet fever. J. Hyg., 1928, 28, 250.

82. Douglas, R., Smith, J., Sutherland, I. N., and Watson, R. J. P., A milk-spread epidemic of scarlet fever. J. Hyg., 1941, 41, 543.

83. Watson, R., An outbreak of milk-borne scarlet fever and tonsillitis in Doncaster. Brit. M. J., 1937, 1, 1189.

84. Lange, H. F., and Gaustad, V., Epidemiology of scarlet fever illustrated through typing of hemolytic streptococci in a primary case and its return cases. Acta paediat., 1942, 29, 254.

85. Evans, A. C., Types of streptococci associated with bovine mastitis followed by outbreaks of human disease. J. Infect. Dis., 1946, 78, 18.

86. Evans, A. C., The distribution of the various agglutinative types of hemolytic streptococci of group A. J. Infect. Dis., 1946, 78, 1.

87. Griffith, F., The serological classification of streptococcus pyogenes. J. Hyg., 1935, 34, 542.

88. McMillan, J. C., Jr., Seventy-eight hundred scarlet fever patients. U. S. Nav. Med. Bull., 1946, 46, 89.
89. Jennings, R., and De Lamater, E. D., Penicillin therapy of scarlet fever and the streptococcus carrier. Am. J. Med., 1947, 2, 1.

90. Wilson, O. G., An outbreak of sulfadiazine resistant streptococcus infection at Lowry Field, Colorado. J. Infect. Dis., 1946, 78, 147.

91. Commission on Acute Respiratory Diseases, A study of a food-borne epidemic of tonsillitis and pharyngitis due to $\beta$-hemolytic streptococcus, type 5 . Bull. Johns Hopkins Hosp., 1945, 77, 143.

92. Swift, H. F., Wilson, A. T., and Lancefield, R. C., Typing group $\mathbf{A}$ hemolytic streptococci by $\mathbf{M}$ precipitin reactions in capillary pipettes. J. Exper. Med., 1943, 78, 127.

93. Hilles, C. H., and Hamburger, M., Jr., Experience with the slide agglutination and the capillary precipitin methods for typing hemolytic streptococci. J. Infect. Dis., 1944, 75, 265.

94. Capps, J. A., Epidemic streptococcus sore throatits symptoms, origin and transmission. J. A. M. A., 1913, 61, 723.

95. Maxted, W. R., Preparation of streptococcal extracts for Lance-field grouping. Lancet, 1948, 2, 255.

96. Rammelkamp, C. H., Jr., Weaver, R. S., and Dingle, J. H., Significance of the epidemiological differences between acute nephritis and acute rheumatic fever. Tr. A. Am. Physicians, 1952, 65, 168.

97. Rammelkamp, C. H., Jr., Stetson, C. A., Krause, R. M., Kohen, R., and Perry, W. D. To be published.

98. Dingle, J. H., Badger, G. F., Feller, A. E., Hodges, R. G., Jordan, W. S., Jr., and Rammelkamp, C. H., Jr., A study of respiratory infections in families. Tr. A. Am. Physicians, 1949, 62, 99.

99. Feldman, H. A., Personal communication.

100. Kempe, C. H., Olmsted, R. W., and Curnen, E. C., Outbreak of acute nephritis in adolescent school boys. Pediatrics, 1951, 8, 393.

101. Manser, R. W. E., and Wilson, M. M., An epidemic of haemolytic streptococcal (group A) infection associated with a considerable incidence of acute nephritis. Med. J. Australia, 1952, 2, 339.

102. Langmuir, A. D., Richardson, C., Jr., and Perry, C. A., Personal communication.

103. Denny, F. W., and Thomas, L., Personal communication.

104. Coburn, A. F., and Young, D. C., The Epidemiology of Hemolytic Streptococcus During World War II in the United States Navy. Williams \& Wilkins, Baltimore, 1949.

105. Seegal, D., and Earle, D. P., Jr., A consideration of certain biological differences between glomerulonephritis and rheumatic fever. Am. J. M. Sc., 1941, 201, 528.

106. Kuttner, A. G., and Krumwiede, E., Observations on the effect of streptococcal upper respiratory infections on rheumatic children: a three year study. J. Clin. Invest., 1941, 20, 273. 
107. Rammelkamp, C. H., Jr., Denny, F. W., and Wannamaker, L. W., Studies on the Epidemiology of Rheumatic Fever in the Armed Services, in Rheumatic Fever, A Symposium, Thomas, L., editor. University of Minnesota Press, Minneapolis, 1952.

108. Seegal, D., Seegal, E. B. C., and Jost, E. L., A comparative study of the geographic distribution of rheumatic fever, scarlet fever, and acute glomerulonephritis in North America. Am. J. M. Sc., $1935,190,383$.

109. Wilson, M. G., Rheumatic Fever. Studies of the Epidemiology, Manifestations, Diagnosis, and Treatment of the Disease During the First Three Decades. The Commonwealth Fund, New York, 1940.

110. Hamburger, M., Jr., Hilles, C. H., Hamburger, V. G., Johnson, M. A., and Wallin, J. G., Ability of different types of hemolytic streptococci to produce scarlet fever. J. A. M. A., 1944, 124, 564.
111. Wright, F. H., Personal communication.

112. Wertheim, A. R., Lyttle, J. D., Loeb, E. N., Earle, D. P., Jr., Seegal, B. C., and Seegal, D., The association of type specific hemolytic streptococci with acute glomerulonephritis at the Presbyterian and Babies Hospitals, New York, N. Y., in the years 1936-1942. J. Clin. Invest., 1953, 32, 359.

113. Rantz, L. A., Hemolytic streptococcus otitis media. Stanford Med. Bull., 1952, 10, 32.

114. Watson, R. F., and Lancefield, R. C., Studies on the antigenic composition of group $A$ hemolytic streptococci. III. Types with serologically identical $M$ but distinct $\mathrm{T}$ antigens: types 10 and 12 . J. Exper. Med., 1944, 79, 89.

115. Wannamaker, L. W., Denny, F. W., and Perry, W. D., To be published.

116. Rammelkamp, C. H., Jr., and Weaver, R. S., Unpublished observations. 